\title{
Aplikasi Interdigital Capacitor Sensor (IDCS) dalam Pengukuruan Relatif Crude Oil
}

\author{
${ }^{1}$ Risse Entikaria Rachmanita, ${ }^{2}$ Haerul Ahmadi \\ 1 Prodi Teknik Energi Terbarukan, Politeknik Negeri Jember, Jember 68121, Indonesia \\ 2 Prodi Teknik Fisika Nuklir, Sekolah Tinggi Teknologi Nuklir, Kab. Sleman 55281, Indonesia \\ e-mail: risse_rachmanita@polije.ac.id; haerul.ahmadi@sttn-batan.ac.id
}

\begin{abstract}
Abstrak
Interdigital Capacitor Sensor (IDCS) telah diaplikasikan dalam berbagai bidang, terutama pada bidang kimia dan biologi. Penelitian ini bertujuan untuk melakukan pengukuran permitivitas relatif pada crude oil dengan mengaplikasikan IDCS sebagai media sensing. Permitivitas relatif sangat dibutuhkan untuk mendapatkan sifat kelistrikan, yang metodenya masih jarang didapatkan pada special liquid seperti pada crude oil. IDCS dapat dimanfaatkan untuk aplikasi pada pengukuran microlevel crude oil. IDCS dicetak pada printed circuit board (PCB) dengan konfigurasi dua pola sisir elektroda. Sensor yang telah dibuat memiliki 5 elektroda di setiap sisinya, panjang elektroda adalah $40 \mathrm{~mm}$, lebar elektroda adalah $4 \mathrm{~mm}$, tebal elektroda adalah $0,01 \mathrm{~mm}$, dan jarak antar elektroda adalah $5 \mathrm{~mm}$. Kalibrasi IDCS menggunakan RCL meter tipe PM 6303A Philip frekuensi $1 \mathrm{kHz}$. Pengujian sensor dilakukan dengan pengukuran kapasitansi IDCS sendiri dan pengukuran kapasitansi aquades. Selanjutnya, dilakukan pengukuran kapasitansi crude oil menggunakan IDCS yang telah dikalibrasi. Hasil pengukuran diperoleh nilai rata-rata kapasitansi IDCS (tembaga), air murni, dan crude oil berturut-turut adalah $(22,7 \pm$ $0,6) \mathrm{pF},(1,12 \pm 0,05) \mathrm{nF}$, dan $(25,6 \pm 0,6) \mathrm{pF}$. Hasil perhitungan dari data kapasitansi diperoleh permitivitas relatif IDCS (tembaga), air murni, dan crude oil berturut-turut adalah 17,2 $\pm 0,4$, $71,89 \pm 1,67$, dan $2,4 \pm 0,2$. Nilai kapasitansi bahan uji berbanding lurus dengan nilai permitivitas relatifnya.
\end{abstract}

Kata Kunci: kapasitansi; permitivitas relative; crude oil; IDCS.

\section{Interdigital Capacitor Sensor (IDCS) Application in Measuring Relative Crude Oil}

\begin{abstract}
Interdigital capacitor sensor (IDCS) has been applied in various fields, especially in chemistry and biology. This study aims to measure the relative permittivity of crude oil by applying IDCS as a sensing media. Relative permitivity is needed to obtain electrical properties, the method of which is still rarely found in special liquids such as crude oil. IDCS can be used for applications in measuring microlevel crude oil. IDCS is printed on a printed circuit board (PCB) with two comb pattern. This sensor has five electrodes on each side, the length of the electrodes is 40 $\mathrm{mm}$, the width of the electrodes is $4 \mathrm{~mm}$, the thick of the electrodes is $0.01 \mathrm{~mm}$, and the distance between the electrodes is $5 \mathrm{~mm}$. This sensor is calibrated by measuring the capacitance of IDCS itself and capacitance of pure water using RLC meter 6303A type PM Philip $1 \mathrm{kHz}$. Furthermore, the measurement capacitance of crude oil by using the IDCS that has been calibrated. The measurement show that the average value of capacitance film (copper), pure water, and crude oil respectively are $(22.7 \pm 0.6) \mathrm{pF},(1.12 \pm 0.05) \mathrm{nF}$, and $(25.6$ $\pm 0.6) \mathrm{pF}$. The calculation result show that the average value of relative permittivity film (copper), pure water, and crude oil respectively are $17.2 \pm 0.4,71.89 \pm 1.67$, and $2.4 \pm 0.2$. The capacitance value of fluid is directly proportional to the dielectric constant value of fluid.
\end{abstract}

Keywords: capacitance; relative permittivity; crude oil; IDCS.

How to Cite: Rachmanita, R., \& Ahmadi, H. (2019). Aplikasi Interdigital Capacitor Sensor (IDCS) dalam pengukuran permitivitas relatif Crude Oil. Jurnal Pendidikan Fisika dan Keilmuan (JPFK), 5(2), 72-82. doi:http://dx.doi.org/10.25273/jpfk.v5i2.4011 


\section{PENDAHULUAN}

Setiap bahan dielektrik memiliki karakteristik masing - masing. Karakteristik bahan dielektrik bisa dibedakan melalui konstanta dielektrik $\left(\varepsilon_{r}\right)$, susceptibilitas $\left(\chi_{e}\right)$, dan permitivitasnya $(\varepsilon)$. Permitivitas bahan adalah besarnya energi listrik yang disimpan dalam bahan dengan menerapkan tegangan, relatif terhadap yang tersimpan dalam vakum. Dengan mengetahui nilai permitifitas dari bahan kita dapat mengetahui sifat kelistrikan dari bahan tersebut. Permitivitas suatu bahan mempengaruhi besar kapasitansi bahan tersebut. Semakin besar permitivitas bahan semakin besar kapasitansinya. Kapasitansi merupakan kemampuan kapasitor untuk menyimpan muatan listrik untuk beda potensial yang telah ditentukan. Kapasitansi suatu bahan bisa diketahui dengan menggunakan Interdigital Capacitor Sensor (IDCS) sebagai media sensing.

Interdigital Capacitor Sensor (IDCS) merupakan kapasitor berbentuk konfigurasi elektroda yang periodik yang cara kerjanya sama dengan kapasitor pelat sejajar(Syaifudin dkk., 2009). Secara operasional, prinsip IDCS sama halnya dengan kapasitor plat sejajar. Salah satu kutubnya dihubungkan pada sumber tegangan dan kutub lainnya dihubungkan dengan ground, antara kedua kutub terbentuk medan magnet. Perubahan medan magnet mengindikasikan perubahan nilai impedansi dari sensor. Jika terdapat suatu stimulus pada bidang dielektrikum, maka menyebabkan perubahan nilai kapasitansi dari sensor (Rachmanita dkk., 2018). IDCS telah digunakan sejak tahun 1970 dalam aplikasi kontrol pada proses pengasapan, penelitian komponen dielektrik keramik dan polimer film, fabrikasi pada komponen elektronik seperti filter gelombang mikro, perlengkapan akustik, aplikasi pada transducer, dalam bidang kimia dan biologi (Igreja \& Dias, 2011). Selain itu aplikasi IDCS diterapkan kualitas bahan makanan, mendekteksi kandungan bahan kimia yang berbahaya pada bahan makanan laut (Syaifudin dkk., 2009), dan deteksi tetes fluida mikro (Cole \& Kenis, 2009). Pada penelitian ini IDCS diaplikasikan sebagai media sensing dalam pengukuran permitivitas crude oil. Permitivitas relatif sangat dibutuhkan untuk mendapatkan sifat kelistrikan, yang metodenya masih jarang didapatkan pada special liquid seperti pada crude oil. IDCS dapat dimanfaatkan untuk aplikasi pada pengukuran microlevel crude oil.

Dalam kamus minyak dan gas bumi, minyak bumi atau crude oil adalah campuran berbagai hidrokarbon yang terdapat dalam bentuk fase cair dalam reservoir di bawah permukaan tanah dan tetap cair pada tekanan atmosfer setelah melalui fasilitas pemisah di atas permukaan (Muntini dkk., 2017). Penyusun utama crude oil adalah karbon dan hidrogen dengan jumlah sulfur yang lebih kecil $(0,1-$ $8 \%)$, nitrogen $(0,1-1,0 \%)$, oksigen $(0,1-3 \%)$ dan elemen lain seperti vanadium, nikel, besi dan tembaga pada tingkat part per million (ppm) sebagai senyawa nonhidrokarbon (Shanmugam, 2012). Langkah penting dalam pengolahan crude oil adalah pemanasan crude oil. Proses ini bertujuan untuk menghilangkan uap dan mengurangi viskositas crude oil. Ada beberapa sifat fisik yang mempengaruhi proses pemanasan crude oil, seperti permitivitas, konduktivitas, viskositas, dan intensitas medan listrik (Hemmingsen dkk., 2006). Sehingga diperlukan pengukuran permitivitas crude oil.

Angkawisittpan dan Manasri (2012) telah melakukan penelitian mengunakan IDCS untuk medeteksi kandungan gula dalam larutan gula. Hasil penelitiannya memperlihatkan bahwa IDCS berpotensi besar untuk mendeteksi permitivitas relatif dan konsentrasi dari larutan gula (Angkawisittpan \& Manasri, 2012). Modul IDCS ini juga berhasil digunakan untuk mnguji level cairan, kapasitansi cairan, dan deteksi biotoksin air laut yang berbahaya dalam makanan laut. Hasil penelitian diperoleh 
dari pengukuran perubahan nilai kapasitansi IDCS karena perubahan perlakuan pada bahan yang diuji (Chetpattananondh dkk., 2014; Oje dkk., 2019; Rukavina, 2014) Pada tahun 2014, J.E Carlson et al telah berhasil mengestimasikan memperkirakan sifat kedielektrikan crude oil berdasarkan metode IR spectroscopy (Carlson dkk., 2014). Yang membedakan penelitian ini dengan penelitian sebelumnya yaitu menggunakan IDCS dari bahan PCB dengan lapisan tembaga (Cu) sebagai elektrodanya yang digunakan untuk media sensing pengukuran permitivitas relatif crude oil. Dengan adanya penelitian ini, pengukuran permitivitas relatif fluida khususnya crude oil menggunakan IDCS menjadi lebih mudah dalam fabrikasi dan instalasi sistem, biaya yang relatif murah dan mudah didapatkan. Permitivitas relatif sangat dibutuhkan untuk mendapatkan sifat kelistrikan, yang metodenya masih jarang didapatkan pada special liquid seperti pada crude oil. Data permitivitas relatif crude oil akan bermanfaat dalam proses pemanasan crude oil menggunakan gelombang mikro (Muntini dkk., 2017).

\section{METODE PENELITIAN}

\section{Insrumentasi dan Bahan}

Alat ukur yang digunakan untuk sistem sensor IDCS yakni: RCL meter tipe PM 6303A Phillip $1 \mathrm{kHz}$ untuk mendeteksi perubahan nilai kapasitansi, dan gelas kimia. Bahan uji yang digunakan dalam pengujian adalah aquades dan crude oil.

Prosedur Pengerjaan

Pengerjaan perancangan sensor yang telah dilakukan, dapat dibagi menjadi tiga tahap, diantaranya adalah:

1. Pembuatan IDCS

Pada tahap ini dilakukan perancangan desain IDCS dengan spesifikasi pada Tabel 1. Desain rancangan konfigurasi IDCS dan hasil cetakan pada PCB seperti pada Gambar 1.

Tabel 1. Spesifikasi IDCS

\begin{tabular}{cc}
\hline Parameter & Ukuran \\
\hline Jumlah elektroda $(\mathrm{N})$ & $10 \mathrm{buah}$ \\
Panjang elektroda (L) & $4 \mathrm{~cm}$ \\
Lebar elektroda (a) & $4 \mathrm{~mm}$ \\
Gap antar elektroda (b) & $5 \mathrm{~mm}$ \\
Ketebalan elektroda (t) & $0.01 \mathrm{~mm}$ \\
\hline
\end{tabular}

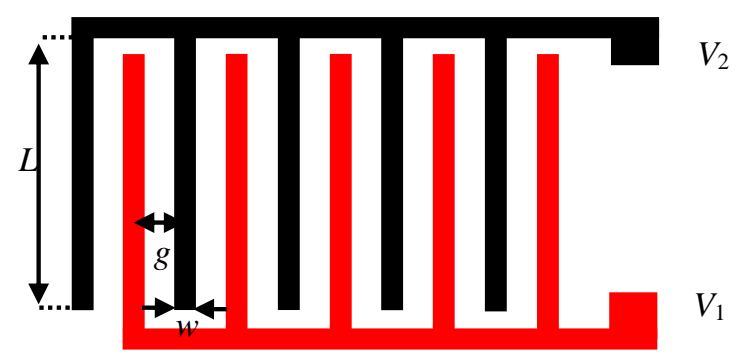

(a) 


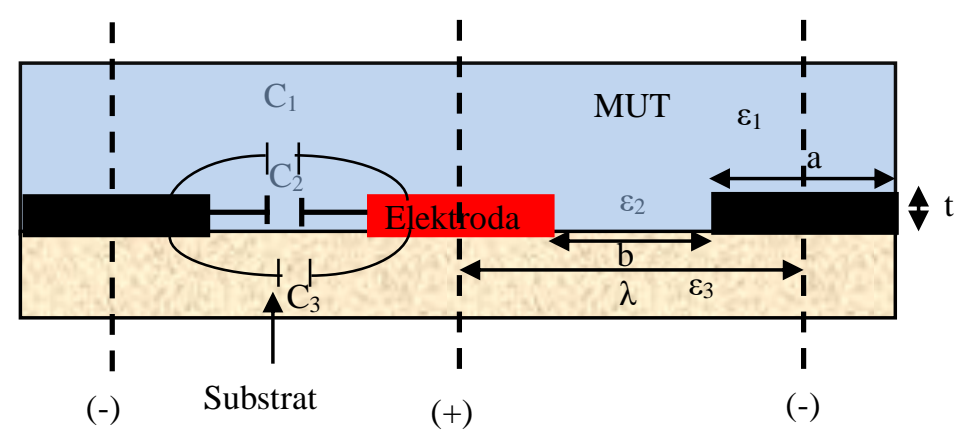

(b)

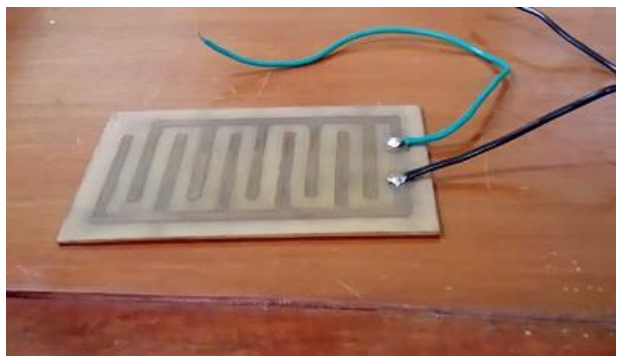

(c)

Gambar 1. (a) Tampak atas bentuk dan konfigurasi elektroda interdigital capasitor sensor (IDCS),

(b) Tampak dari samping konfigurasi elektroda dan

(c) Desain IDCS yang telah dibuat.

Hubungan antara kapasitansi persatuan panjang dan permitivitas dapat dilihat dari persamaan berikut:

$$
C_{u c}=\varepsilon_{0}\left(\varepsilon_{r}+\varepsilon_{k}\right) \frac{\kappa\left(\sqrt{1-\left(\frac{a}{b}\right)^{2}}\right)}{\kappa\left(\frac{a}{b}\right)}+2 \varepsilon_{0} \varepsilon_{k} \frac{t}{a}
$$

Dimana, $\varepsilon_{0}$ adalah permitivitas udara atau ruang hampa, $\varepsilon_{r}$ adalah permitivitas relatif substrat, $\varepsilon_{k}$ adalah permitivitas relatif film, $\kappa$ adalah complete elliptic integral of the first kind, $t$ adalah ketebalan elektroda, a adalah lebar elektroda dan $b$ adalah jarak antar elektroda.

Sedangkan untuk menghitung kapasitansi total, adalah:

$$
C_{\text {TOTAL }}=C_{u c}(N-1) L
$$

Dimana, $N$ adalah jumlah sel elektroda dan $L$ adalah panjang sel elektroda (Abu-Abed \& Lindquist, 2008; Rachmanita, 2019; Rachmanita dkk., 2018).

2. Kalibrasi alat

Kalibrasi RCL meter tipe PM 6303A Phillip dengan cara mengukur kapasitor yang sudah ada nilai kapasitansinya. Jika nilai yang terukur sesuai dengan nilai sebenarnya, maka alat ini sudah bisa digunakan.

3. Pengujian Sensor

Pada tahap ini dilakukan pengujian sensor untuk mendeteksi kapasitansi IDCS sendiri dan kapasitansi aquades. Pengukuran kapasitansi dilakukan dengan menggunakan RLC meter, dan sensor dikontakkan langsung dengan fluida seperti Gambar 2 (a) dan (b). 
Setelah dilakukan pengukuran kemudian dilakukan perhitungan terhadap nilai permitivitas relatif fluida menggunakan modifikasi dari persamaan (1) dan (2), yaitu:

$$
C_{u c}=\frac{C_{\text {TOTAL }}}{(N-1) L}
$$

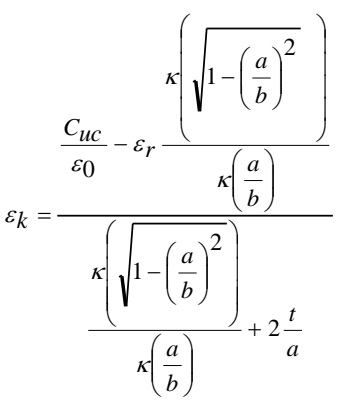

$$
\varepsilon_{r}=\frac{\frac{C_{u c}}{\varepsilon_{0}}-\varepsilon_{k}\left(\frac{\kappa \sqrt{1-\left(\frac{a}{b}\right)^{2}}}{\kappa\left(\frac{a}{b}\right)}+2 \frac{t}{a}\right)}{\kappa\left(\sqrt{1-\left(\frac{a}{b}\right)^{2}}\right)}
$$

Dimana Ctotal adalah kapasitansi hasil pengukuran dan Cuc adalah kapasintasi relatif bahan. adalah complete elliptic integral of the first kind diperoleh dengan kalkulator online. Menggunakan persamaan (3) dan (4) didapatkan data permitivitas IDCS film seperti pada Tabel 2. Dengan menggunakan persamaan (3) dan (5) didapatkan nilai permitivitas relatif aquades seperti pada Tabel 3.

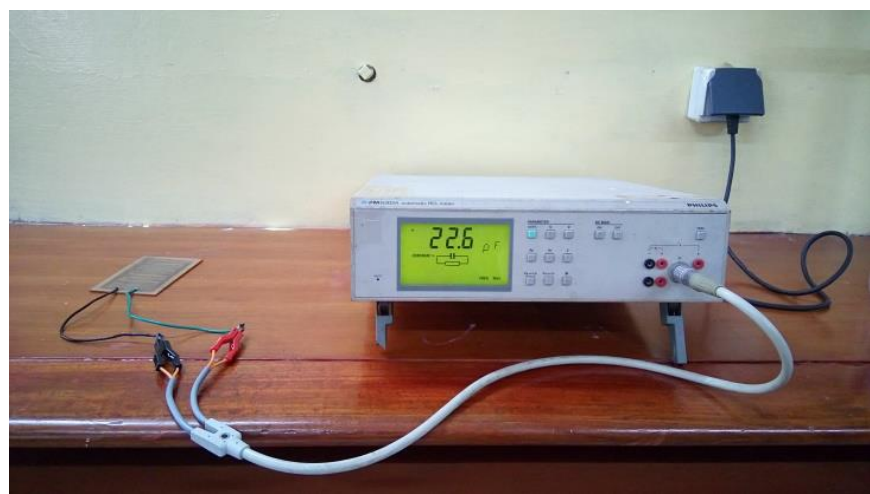

(a) 


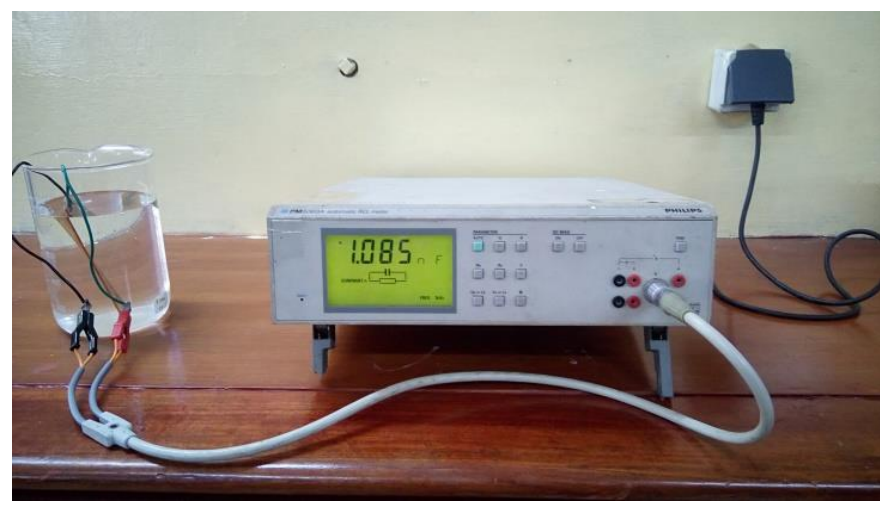

(b)

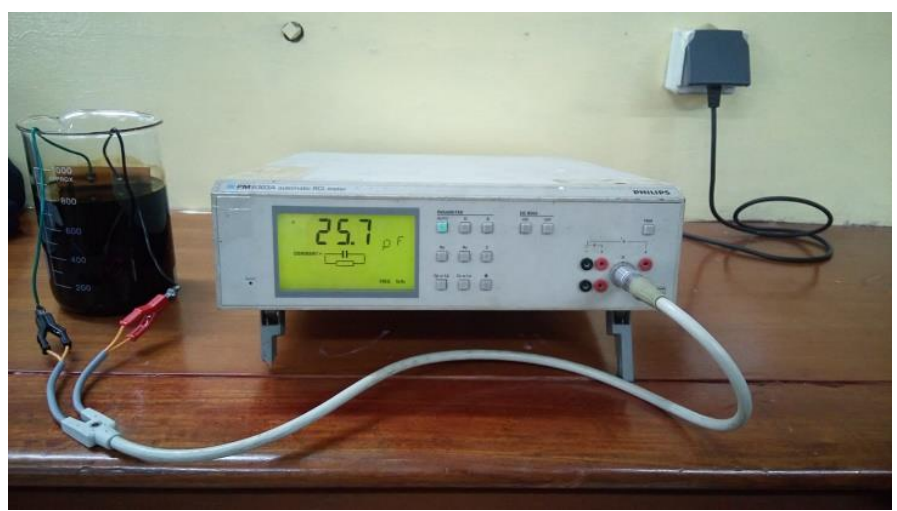

(c)

Gambar 2. Pengujian IDCS (a) Pengukuran kapasitansi IDCS, (b) Pengukuran kapasitansi aquades dan (c) Pengukuran kapasitansi crude oil.

4. Pengukuran Kapasitansi Crude Oil

Pada tahap ini dilakukan pengukuran kapastansi crude oil seperti pada Gambar 2 (c). Nilai permitivitas relatif crude oil dihitung dengan menggunakan persamaan (3) dan (5) sehingga didapatkan data seperti pada Tabel 4.

Pengukuran kapasitansi IDCS, aquades dan crude oil dilakukan berulang, masing-masing sebanyak 10 kali. Nilai kesalahan (error) dihitung dengan menggunakan persamaan (6). Persamaan (6) diperoleh dari penurunan persamaan (3), (4) dan (5) (Rachmanita, 2019).

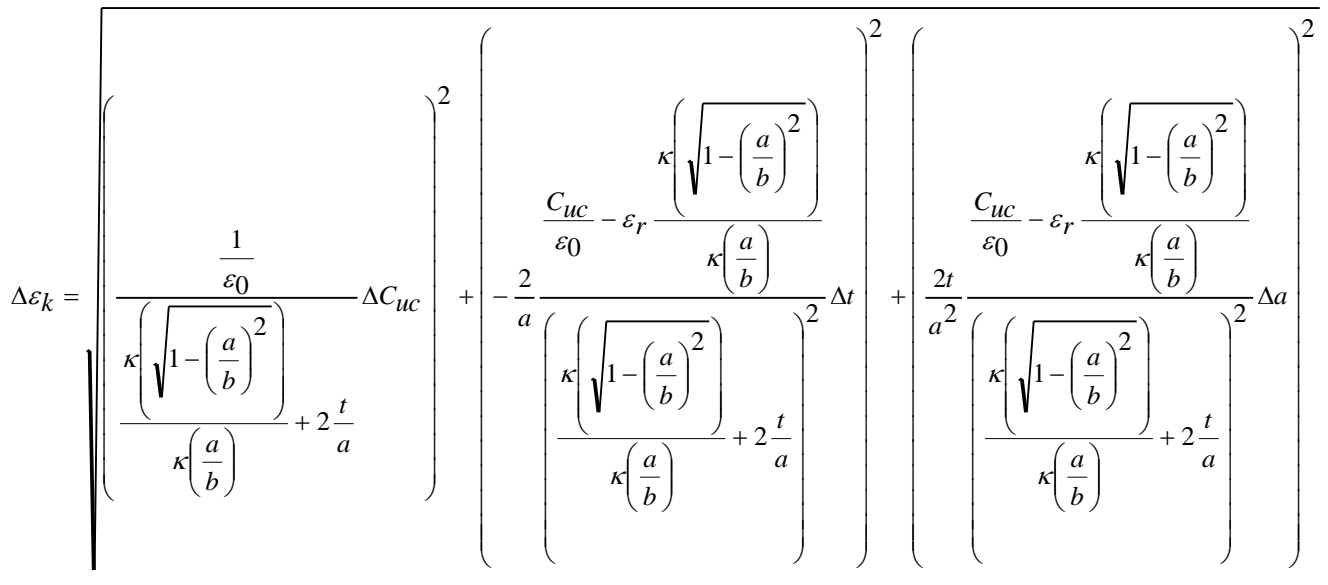

(6) 


\section{HASIL DAN PEMBAHASAN}

IDCS yang telah difabrikasi memiliki spesifikasi jumlah elektroda (N) 10 buah, panjang elektroda (L) 4cm, lebar elektroda (a) $4 \mathrm{~mm}$, gap antar elektroda (b) $5 \mathrm{~mm}$ dan tebal elektroda $0,01 \mathrm{~mm}$. IDCS dihubungkan dengan RCL meter tipe PM 6303A Phillip $1 \mathrm{kHz}$ untuk mengukur kapasitansi IDCS, aquades dan crude oil. Data hasil pengukuran kapasitansi digunakan untuk menghitung nilai permitivitas relatif IDCS film, aquades dan crude oil.

Hasil pengukuran dan perhitungan nilai kapasitansi dan permitivitas relatif IDCS film, aquades dan crude oil masing-masing ditunjukkan pada Tabel 2, 3 dan 4.

Tabel 2. Hasil Pengukuran kapasitansi IDCS dan Perhitungan Permitivitas relatif IDCS film

\begin{tabular}{ccccc}
\hline No. & $\boldsymbol{C}_{\text {total }}(\mathbf{p F})$ & $\boldsymbol{C}_{\mathbf{u c}}(\mathbf{p F} / \mathbf{m})$ & $\boldsymbol{\varepsilon}_{\mathbf{k}}$ & $\boldsymbol{E} \boldsymbol{\text { rror }}(\boldsymbol{\%})$ \\
\hline 1 & 22,5 & 140,6 & 17,0 & 0,22 \\
2 & 22,6 & 141,3 & 17,1 & 0,22 \\
3 & 22,6 & 141,3 & 17,1 & 0,22 \\
4 & 22,6 & 141,3 & 17,1 & 0,22 \\
5 & 22,6 & 141,3 & 17,1 & 0,22 \\
6 & 22,6 & 141,3 & 17,1 & 0,22 \\
7 & 22,8 & 142,5 & 17,3 & 0,22 \\
8 & 22,8 & 142,5 & 17,3 & 0,22 \\
9 & 22,8 & 142,5 & 17,3 & 0,22 \\
10 & 22,8 & 142,5 & 17,3 & 0,22 \\
\hline
\end{tabular}

Tabel 3. Hasil pengukuran kapasitansi aquades dan perhitungan permitivitas relatifnya

\begin{tabular}{ccccc}
\hline No. & $\boldsymbol{C}_{\text {total }}(\mathbf{n F})$ & $\boldsymbol{C}_{\text {uc }}(\mathbf{n F} / \mathbf{m})$ & $\boldsymbol{\varepsilon}_{\boldsymbol{r}}$ & $\boldsymbol{E r r o r} \boldsymbol{( \% )}$ \\
\hline 1 & 1,09 & 6,81 & 69,55 & 0,46 \\
2 & 1,09 & 6,81 & 69,55 & 0,46 \\
3 & 1,09 & 6,81 & 69,55 & 0,46 \\
4 & 1,11 & 6,94 & 71,16 & 0,45 \\
5 & 1,13 & 7,06 & 72,77 & 0,44 \\
6 & 1,13 & 7,06 & 72,77 & 0,44 \\
7 & 1,13 & 7,06 & 72,77 & 0,44 \\
8 & 1,14 & 7,13 & 73,58 & 0,44 \\
9 & 1,14 & 7,13 & 73,58 & 0,44 \\
10 & 1,14 & 7,13 & 73,58 & 0,44 \\
\hline
\end{tabular}

Tabel 4. Hasil pengukuran kapasitansi dan perhitungan permitivitas relatif crude oil

\begin{tabular}{cllll}
\hline No. & $\boldsymbol{C}_{\text {total }}(\mathbf{p F})$ & $\boldsymbol{C}_{\text {uc }}(\mathbf{p F} / \mathbf{m})$ & $\boldsymbol{\varepsilon}_{\boldsymbol{r}}$ & $\boldsymbol{E r r o r}(\boldsymbol{\%})$ \\
\hline 1 & 25,2 & 157,5 & 2,1 & 0,20 \\
2 & 25,3 & 158,1 & 2,2 & 0,20 \\
3 & 25,4 & 158,8 & 2,2 & 0,20 \\
4 & 25,4 & 158,8 & 2,2 & 0,20 \\
5 & 25,5 & 159,4 & 2,3 & 0,20 \\
6 & 25,5 & 159,4 & 2,3 & 0,20 \\
7 & 25,7 & 160,6 & 2,5 & 0,19 \\
8 & 25,8 & 161,3 & 2,6 & 0,19 \\
9 & 25,9 & 161,9 & 2,6 & 0,19 \\
10 & 25,9 & 161,9 & 2,6 & 0,19 \\
\hline
\end{tabular}


Berdasarkan data pada Tabel 2, kita ketahui bahwa nilai kapasitansi IDCS yang diukur berulang 10 kali menghasilkan nilai yang hampir sama, dengan nilai rata-rata $22,7 \pm 0,6 \mathrm{pF}$. Nilai permitivitas relatif dihitung dengan menggunakan persamaan (3) dan (5) dan menghasilkan nilai yang relatif sama. Nilai rata-rata permitivitas relatif IDCS dengan material film tembaga adalah $17,2 \pm 0,4$. Nilai permitivitas relatif permitivitas tembaga berdasarkan referensi adalah 18,1 (Dielectric Constant Table, 2016). Hasil pengukuran dan perhitungan mendekati nilai referensi acuan.

Hasil pengukuran kapasitansi dan perhitungan permitivitas relatif aquades diperlihatkan pada Tabel 3. Berdasarkan data tersebut, nilai kapasitansinya yang diperoleh relatif sama. Nilai rata-rata kapasitansi aquades dengan $10 \mathrm{kali}$ pengukuran berulang adalah 1,12 $\pm 0,05 \mathrm{nF}$. Dengan menggunakan persamaan (3) dan (5) didapatkan nilai rata-rata permitivitas relatif aquades pada frekuensi $1 \mathrm{kHz}$ adalah $71,89 \pm 1,67$ pada suhu $28^{\circ} \mathrm{C}$. Nilai permitivitas relatif air dengan model Debye pada frekuensi rendah $1-10 \mathrm{kHz}$, yaitu 78,3-0,0007j (Angkawisittpan \& Manasri, 2012). Pada air murni, sifat dielektriknya didefinisikan melalui persamaan Debye sebagai berikut:

$$
\begin{gathered}
\varepsilon_{\mathrm{rw}}=\varepsilon_{\mathrm{rwH}}+\frac{\varepsilon_{\mathrm{rwL}}-\varepsilon_{\mathrm{rwH}}}{1+\omega^{2} \tau_{\mathrm{w}}^{2}} \\
\tan \delta_{\mathrm{w}}=\frac{\left(\varepsilon_{\mathrm{rwL}}-\varepsilon_{\mathrm{rwH}}\right) \omega \tau_{\mathrm{w}}}{\varepsilon_{\mathrm{rwL}}+\varepsilon_{\mathrm{rwH}} \omega^{2} \tau_{\mathrm{w}}^{2}}
\end{gathered}
$$

Di mana $\varepsilon_{\mathrm{rwH}}$ adalah permitivitas relatif atau konstanta dielektrik pada batas frekuensi tinggi (tidak berdimensi), $\varepsilon_{\text {rwL }}$ adalah konstanta dielektrik statis air murni (tidak berdimensi), $\tau_{\mathrm{w}}$ adalah waktu relaksasi air murni (s), $\omega$ adalah frekuensi sudut $(\mathrm{rad} / \mathrm{s})$, dan $\tan \delta_{\mathrm{w}}$ adalah koefisisen sudut loss dielektrik (Erdogan dkk., 2011; Ratanadecho dkk., 2002). Berdasarkan data referensi lain nilai permitivitas relatif aquades adalah 80,4 pada suhu $20^{\circ} \mathrm{C}$. Nilai konstanta dielektrik/permitivitas relatif aquades yang diperoleh dari eksperimen sesuai dengan hasil penelitian sebelumnya. Hasil kalibrasi IDCS dengan pengukuran permitivitas relatif IDCS dan aquades diperoleh hasil yang sesuai dengan hasil penelitian sebelumnya, sehingga IDCS yang telah dibuat dapat digunakan untuk pengukuran selanjutnya, yaitu pengukuran kapasitansi crude oil.

Data pada Tabel 4 menunjukkan bahwa hasil pengukuran 10 kali kapasitansi crude oil hampir sama. Nilai rata-rata kapasitansi crude oil adalah $25,6 \pm 0,6 \mathrm{pF}$. Dengan menggunakan persamaan (3) dan (5) didapatkan nilai rata-rata permitivitas relatif crude oil adalah 2,4 $\pm 0,2$ pada frekuensi $1 \mathrm{kHz}$. Berdasarkan penelitian sebelumnya yang dilakukan oleh Johan $\mathrm{E}$. Carlson et al. diperoleh nilai permitivitas relatif crude oil pada rentang 2,1 - 2,7 sesuai dengan jenis sampel crude oil yang diuji menggunakan metode IR Spectroscopy (Carlson dkk., 2014). Hal ini menunjukan bahwa nilai permitivitas relatif crude oil yang diperoleh sesuai dengan referensi acuan. 


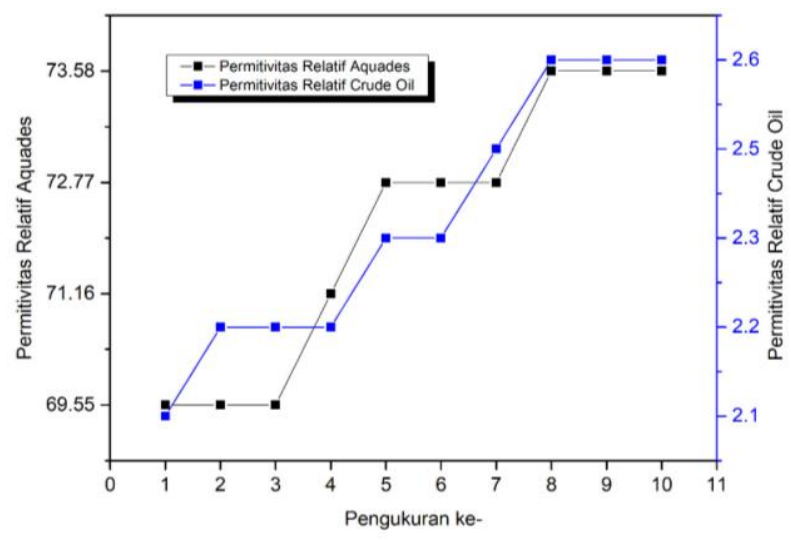

Gambar 3. Permitivitas relatif aquades dan crude oil.

Nilai kapasitansi crude oil lebih kecil dari kapasitansi aquades pada suhu ruang dan frekuensi $1 \mathrm{kHz}$ yaitu 25,6 $\mathrm{pF}: 1,12 \mathrm{nF}$ atau $\pm 0,023$ kali dari kapasitansi aquades seperti diperlihatkan pada Tabel 3 dan 4 . Sehingga berpengaruh terhadap nilai permitivitas relatif masing-masing fluida. Nilai permitivitas relatif crude oil lebih kecil dari aquades pada suhu ruang dan frekuensi $1 \mathrm{kHz}$ yaitu 2,4:71,89 atau $\pm 0,033$ kali nilai permitivitas relatif aquades seperti pada Gambar 3 .

Semakin besar nilai kapasitansi fluida maka semakin besar nilai permitivitas relatifnya (Angkawisittpan \& Manasri, 2012; Rachmanita dkk., 2018; Rukavina, 2015), sesuai dengan persamaan untuk menghitung kapasitansi pelat sejajar ketika terdapat bahan dielektrik diantara kedua pelat yaitu

$$
C=\frac{\varepsilon_{0} \varepsilon_{r} A}{d}=\frac{\varepsilon A}{d}
$$

dengan adalah permitivitas ruang hampa atau udara $(\mathrm{F} / \mathrm{m})$, adalah permitivitas relatif dan adalah permitivitas relatif bahan dielektrik $(\mathrm{F} / \mathrm{m})$. Selain itu, hubungan antara kapasitansi persatuan panjang dan permitivitas sesuai dengan persamaan (3) di atas.

Kapasitansi dan permitivitas relatif fluida, dalam hal ini crude oil juga dipengaruhi oleh komponen penyusunnya. Komponen penyusun crude oil secara umum terdiri atas senyawa hidrokarbon dan beberapa komponen non-hidrokarbon. Senyawa hidrokarbon merupakan senyawa organik yang hanya memiliki unsur karbon dan hidrogen pada setiap molekulnya. Dalam crude oil senyawa hidrokarbon terdiri atas hidrokarbon parafin, naftan, aromat, monoolefin dan diolefin. Senyawa-senyawa ini memiliki susunan rantai karbon dan titik didih yang berbeda-beda. Sedangkan senyawa non-hidrokarbon dalam crude oil merupakan senyawa organik terdiri atas atom unsur belerang, oksigen, nitrogen dan logamlogam khusus misalnya nikel, besi, tembaga dan vanadium yang jumlahnya relatif sedikit. Komponen penyusun crude oil adalah karbon: 83,0 - 87\%, hidrogen: 10,0 14,0\%, nitrogen: $0,1-2,0 \%$, oksigen: $0,05-1,5 \%$, sulfur: $0,05-6,0 \%$, metal (Ni dan V): $<1000$ ppm (Muntini dkk., 2017). Sehingga nilai permitivitas relatif crude oil di suatu tempat akan sedikit berbeda dengan tempat lain, tergantung dengan prosentase komponen penyusunnya.

Penelitian ini membuktikan bahwa metode pengukuran permitivitas relatif crude oil dengan menggunakan IDCS telah berhasil dilakukan. Pengukuran permitivitas relatif crude oil menjadi lebih mudah dalam fabrikasi dan instalasi sistem pengukuran, biaya lebih murah dan mudah didapatkan. Data permitivitas relatif crude oil sangat diperlukan dalam proses pengolahan minyak khususnya pada tahap pemanasan crude oil. 


\section{KESIMPULAN}

Penelitian ini menghasilkan metode pengukuran permitivitas relatif pada crude oil yang sangat dibutuhkan dalam bidang perminyakan. Metode tersebut adalah Interdigital capacitor sensor (IDCS). Spesifikasi Interdigital capacitor sensor (IDCS) yang dibuat adalah: masing-masiing 5 elektroda positif dan negatif, panjang elektroda adalah $40 \mathrm{~mm}$, lebar elektroda adalah $4 \mathrm{~mm}$, ketebalan elektroda adalah $0.01 \mathrm{~mm}$, dan jarak antar elektroda adalah $5 \mathrm{~mm}$. Dari hasil pengukuran didapatkan nilai rata-rata kapasitansi IDCS (film tembaga), aquades dan crude oil masing-masing adalah $(22,7 \pm 0,6) \mathrm{pF},(1,12 \pm 0,05) \mathrm{nF}$, dan $(25,6 \pm 0,6) \mathrm{pF}$ pada frekuensi $1 \mathrm{kHz}$ dengan nilai kesalahan masing-masing adalah kurang dari 0,5\%.

Hasil perhitungan didapatkan nilai rata-rata permitivitas relatif IDCS (film tembaga), aquades dan crude oil masing-masing adalah 17,2 $\pm 0,4,71,89 \pm 1,67$ and $2,4 \pm 0,2$ pada suhu $28^{\circ} \mathrm{C}$ dan frekuensi $1 \mathrm{kHz}$. Nilai permitivitas relatif crude oil yang diperoleh dari penelitian sesuai dengan penelitian sebelumnya yang menggunakan metode pengukuran IR Spectroscopy. Sehingga metode IDCS berhasil diaplikasikan sebagai sensor permitivitas relatif pada crude oil, yang sampai saat ini masih sulit untuk didapatkan dengan harga yang murah dan metode yang sederhana.

\section{DAFTAR PUSTAKA}

Abu-Abed, A. S., \& Lindquist, R. G. (2008). Capacitive interdigital sensor with inhomogeneous nematic liquid crystal film. Progress In Electromagnetics Research, 7, 75-87. http://www.jpier.org/PIERB/pier.php?paper=08022901

Angkawisittpan, N., \& Manasri, T. (2012). Determination of sugar content in sugar solutions using interdigital capacitor sensor. Measurement Science Review, 12(1), 8-13. https://doi.org/https://doi.org/10.2478/v10048-012-0002-0

Carlson, J. E., Tomren, A. L., Folgerø, K., \& Barth, T. (2014). Estimation of dielectric properties of crude oils based on IR spectroscopy. Chemometrics and Intelligent Laboratory Systems, $139, \quad 1-5$. https://doi.org/https://doi.org/10.1016/j.chemolab.2014.09.001

Chetpattananondh, K., Tapoanoi, T., Phukpattaranont, P., \& Jindapetch, N. (2014). A self-calibration water level measurement using an interdigital capacitive sensor. Sensors and Actuators A: Physical, 209, 175-182. https://doi.org/https://doi.org/10.1016/j.sna.2014.01.040

Cole, M. C., \& Kenis, P. J. (2009). Multiplexed electrical sensor arrays in microfluidic networks. Sensors and Actuators B: Chemical, 136(2), 350-358. https://doi.org/https://doi.org/10.1016/j.snb.2008.12.010

Erdogan, L., Akyel, C., \& Ghannouchi, F. M. (2011). Dielectric properties of oil sands at $2.45 \mathrm{GHz}$ with TE1, 0, 11 mode determined by a rectangular cavity resonator. Journal of Microwave Power and Electromagnetic Energy, 45(1), 15-23. https://doi.org/https://doi.org/10.1080/08327823.2011.11689794

Hemmingsen, P. V., Kim, S., Pettersen, H. E., Rodgers, R. P., Sjöblom, J., \& Marshall, A. G. (2006). Structural characterization and interfacial behavior of acidic compounds extracted from a North Sea oil. Energy \& fuels, 20(5), 1980-1987. https://doi.org/https://doi.org/10.1021/ef0504321

Igreja, R., \& Dias, C. (2011). Extension to the analytical model of the interdigital electrodes capacitance for a multi-layered structure. Sensors and Actuators A: Physical, 172(2),

392-399. https://doi.org/https://doi.org/10.1016/j.sna.2011.09.033

Muntini, M. S., Pramono, Y. H., Minarto, E., Kalsum, U., \& Rachmanita, R. E. (2017). Modeling and simulation of microwave propagation on crude oil heating. 2017 
International Seminar on Sensors, Instrumentation, Measurement and Metrology (ISSIMM),

Oje, A. I., Ogwu, A., Mirzaeian, M., Tsendzughul, N., \& Oje, A. (2019). Pseudocapacitance of silver oxide thin film electrodes in ionic liquid for electrochemical energy applications. Journal of Science: Advanced Materials and Devices, 4(2), 213-222. https://doi.org/https://doi.org/10.1016/j.jsamd.2019.04.003

Rachmanita, R. E. (2019). The High Capacitance for Electrode Structure of Interdigital Capacitor Thin Film Models. SNRU Journal of Science and Technology, 11(2), 55-63. https://ph01.tci-thaijo.org/index.php/snru_journal/article/view/171622

Rachmanita, R. E., Muntini, M. S., Thawankaew, S., Chao-Moo, W., Vora-Ud, A., \& Seetawan, T. (2018). Fabrication and characterization of interdigital capacitors thin film by DC magnetron sputtering for measuring the permittivity of crude oil. Materials Today: Proceedings, 5(7), 15192-15197. https://doi.org/https://doi.org/10.1016/j.matpr.2018.04.081

Ratanadecho, P., Aoki, K., \& Akahori, M. (2002). A numerical and experimental investigation of the modeling of microwave heating for liquid layers using a rectangular wave guide (effects of natural convection and dielectric properties). Applied Mathematical Modelling, 26(3), 449-472. https://doi.org/https://doi.org/10.1016/S0307-904X(01)00046-4

Rukavina, A. V. (2014). Hand-held unit for liquid-type recognition, based on interdigital capacitor. Measurement, 289-296. https://doi.org/https://doi.org/10.1016/j.measurement.2014.02.012

Rukavina, A. V. (2015). Non-invasive liquid recognition based on interdigital capacitor. Sensors and Actuators A: Physical, 228, 145-150. https://doi.org/https://doi.org/10.1016/j.sna.2015.03.019

Shanmugam, G. (2012). Handbook of Petroleum Exploration and Production. In J. Cubbit (Ed.), Handbook of Petroleum Exploration and Production, 9. https://doi.org/https://doi.org/10.1016/B978-0-444-56335-4.00010-2

Syaifudin, A. M., Jayasundera, K., \& Mukhopadhyay, S. (2009). A low cost novel sensing system for detection of dangerous marine biotoxins in seafood. Sensors and Actuators B: Chemical, 137(1), 67-75. https://doi.org/https://doi.org/10.1016/j.snb.2008.12.053 